\title{
Erratum to: Repression of chimeric transcripts emanating from endogenous retrotransposons by a sequence-specific transcription factor
}

\author{
Ka Sin Mak, Jon Burdach, Laura J. Norton, Richard CM Pearson, Merlin Crossley ${ }^{*}$ and Alister PW Funnell
}

In the study [1] a gel depicted in Fig. 2a was labelled in a way which suggests that the sample comes from a $\mathrm{Klf3}^{-/-}$knockout mouse. In fact, this sample comes from a $K l f 3^{-1-}$,Klfg genetrap double mutant animal. The Klf8 genotype was not indicated as authors felt that it was not relevant for the conclusions of this paper; however, all authors now acknowledge that this information should have been included. Importantly, an equivalent result from single $\mathrm{Klf3}^{-1-}$ knockout mice is included and confirmed in the RNA-seq results presented in Figure 6 of the original article [1].

All other data described in the article were obtained from the $\mathrm{Klf3}^{-1-}$ single knockout mice, and as such the conclusions of the article remain unchanged. It is also critical to note that all other results in the article could not have been obtained from the double mutant mice, because Klf3,Klf8 deficient animals die in utero (as reported by the authors in [2]).

Figure 2 with the correct legend is published in this Erratum.

The authors apologize for this omission and any confusion and inconvenience it may have caused.

Received: 5 May 2016 Accepted: 5 May 2016

Published online: 03 June 2016

\section{References}

1. Mak KS, Burdach J, Norton L, Pearson RCM, Crossley M, Funnell APW. Repression of chimeric transcripts emanating from endogenous retrotransposons by a sequence-specific 35 transcription factor. Genome Biol. 2014;15:R58.

2. Funnell APW, Mak KS, Twine NA, Pelka GJ, Norton LJ, Radziewic T, et al. Generation of Mice Deficient in both KLF3/BKLF and KLF8 Reveals a Genetic Interaction and a Role for These Factors in Embryonic Globin Gene Silencing. Mol Cell Biol. 2013;33(15):2976-87.

* Correspondence: m.crossley@unsw.edu.au

School of Biotechnology and Biomolecular Sciences, University of New South Wales, Kensington, NSW 2052, Australia

\footnotetext{
Submit your next manuscript to BioMed Central and we will help you at every step:

- We accept pre-submission inquiries

- Our selector tool helps you to find the most relevant journal

- We provide round the clock customer support

- Convenient online submission

- Thorough peer review

- Inclusion in PubMed and all major indexing services

- Maximum visibility for your research

Submit your manuscript at www.biomedcentral.com/submit
} 


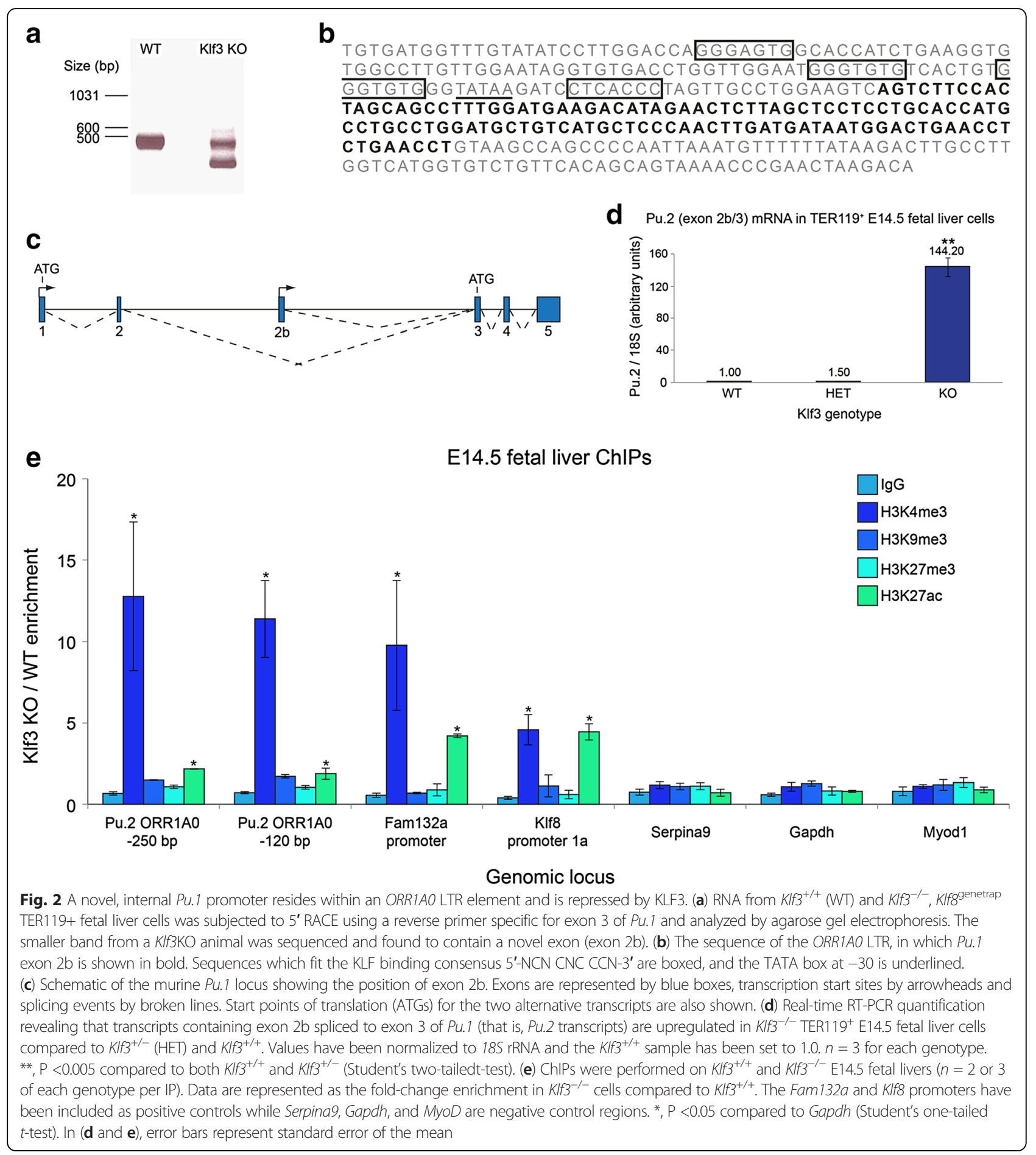

